\title{
Journal of Economics and Administrative Sciences (JEAS)
}

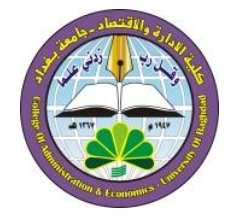

Available online at http://jeasiq.uobaghdad.edu.iq

\section{Investment Trends for Iraqi Industries in Terms of Clean Production (selected model)}

\author{
Mohanad Ali Hussein AL-Munim \\ College of Administration and \\ Economics/University of Baghdad \\ mohanadalmunim2@gmail.com
}

Received: 10/8/2021
Accepted: 5/9/2021
Prof. Dr. Manahel Mustafa Abdul hameed College of Administration and Economics/University of Baghdad manahelalomary@gmail.com

This work is licensed under a Creative Commons Attribution-NonCommercial 4.0 International (CC BY-NC 4.0)

\section{Abstract:}

Industrial Investment according to Clean Productive methods is an important element in the process of rational use of Economic Resources, and the Iraqi industrial sector relied on traditional production methods; the productive activities in this sector did not take into consideration the environmental dimension, which leads to achieving the optimal use of economic resources, so it was necessary to have new investment trends heading with Clean Production. Therefore, the research is based on the hypothesis that "Clean Production contributes to improving the environment and rational use of Natural Resources." Based on the descriptive - inductive analysis methodology that study of Iraqi industries with Clean Production, and by seeking to collect the largest number of data and information related to these industries in order to obtain results and test the research hypothesis.

The research concluded that despite the orientation of some Industries in Iraq towards Clean Production, they do not seek to achieve Sustainability in economic resources. For this, the research concluded that it is necessary to work seriously in harnessing technology, applied and technical sciences to direct Industrial Investment in Iraq towards Clean Products, by finding industrial alternatives that involve Cleaner Production and compensate for the inputs with Environmental damage.

Research paper; Technical paper; Conceptual paper; Case study.

Keywords: Industries, Clean Production (CP), Industrial Investment, Environment ,Linear flow, natural resources 


\section{1- Introduction:}

The diversity of industrial investment and the sources of raw materials and the integration of these sources in Iraq with the availability of diversified energy, where these advantages are imposed to be reflected in the investment in this active sector and the transformations in these industrial investments in order to meet the diverse, developed and growing need of goods and productivity, by clarifying the aspect of Clean Production in Investment for Iraqi industry models. This industrial concept has been concentrated since the establishment of some industries, the style and pattern of production varies according to different production goals and objectives, some of which are concerned with the economic aspect and achieving economic revenues and others from industrial methods that adopt the environmental aspect in addition to the economic aspect. The clean production method is characterized by that it is less pressure on economic resources and maintains the sustainability of natural resources.

The Iraqi industries that take Clean Production as a priority to work with in their procedures to shifts in their production performance and industrial patterns towards clean production, It also focused on the future aspirations of future industries in Clean Production form in order to preserve the general environment and social welfare as a primary objective and economic returns for the sustainability of resources, and in order to reach clean industries that take the protection of the environment in Iraq, industrial policies and their future direction.

The importance: The importance lies in studying the extent to which investment is directed to Iraqi industries in terms of Clean Production, in a way that makes optimal use of economic resources and the level of introducing the environmental dimension in their products.

The aim of the research: to clarify the situation of some Iraqi industries with Clean Production methods in their various orientations in the production process. Research problem: The industrial sector uses different production methods, many of which did not take into account the environmental dimension that achieves the rational use of economic resources, so there are modest trends towards clean industries.

Research hypothesis: The research is based on the hypothesis that "clean production contributes to improving the environment and rational use of natural resources."

Methodology: The methodology depends on descriptive-inductive analysis, through the use of scientific books and reports issued by some Iraqi industrial units under study, in order to achieve the objectives of the study and to test the validity of the hypothesis or not.

\section{2- The Concept of Clean Production:}

In 1989, the United Nations used the term Clean Production as an expression of production in a sustainable manner, which means the prevention and reduction of environmental pollution and the efficient use of environmental resources instead of treatment for pollution and harmful effects, with the achievement of economic profitability, \& Environmental improvement. Clean Production includes measures and modifications of production processes, 
environmentally friendly designs, and clean environment technologies (ElHaggar, 2007: 21).

The United Nations Environment Program states that Clean Production is "a mechanism to promote sustainable development by reducing industrial waste and emissions, by providing and assisting financial and technological resources, so that the progress of a sustainable economy is achieved by reducing environmental costs, in order to achieve developmental benefits for society" (United Nations Environment Program, 2007: 68). Thus, Clean Production is a preventive method, and it is a term that contains the concepts of environmental efficiency, and it does not conflict with economic growth and is not specific to it. Rather, it seeks to make growth sustainable and achieve benefit and profit for all, as well as protecting the environment, preserving natural resources and improving the operational efficiency of industrial investments and competitive capabilities Clean Production includes the conservation of energy and raw materials and the elimination of harmful substances to the environment. Clean production is "a production process through which you eliminate substances polluting the environment before they occur, instead of the traditional high-cost comparison of treating pollution after it occurs." It is also "a continuous dynamic process as a preventive strategy that includes manufacturing, marketing and service operations and its goal is to increase production and economic efficiency and reduce the risks that harm the environment and humans" (El-Haggar, 2007: 256). Or it is "a process by which industrial units are required to adapt and change government policies and procedures" (Sabri, 2010: 248).

The idea of Clean Production arose in the industrial sector at the time in order to improve the situation of traditional industries and generalize them in their current scientific and global form of the prevailing production pattern, especially in developing countries that include several inputs from raw materials such as raw materials, intermediate materials, energy and manpower. The production process is accompanied by products and waste through dynamic process. For this clean method to reduce harmful and toxic waste by focusing on the entire product life cycle at all stages in order to prevent short and long-term risks to the environment and living organisms, through the use of more advanced technology and application of knowledge in changing investment attitudes, industrial design, waste management and production waste is the most difficult stage. The most important thing is to invest in Clean Production (El-Haggar, 2007: 258).

\section{3- Dynamic Models of Investment in Clean Production:}

There are three production methods in the transition to Clean Production, and these methods can be used individually or in combination, and this depends on the nature of the industry, the materials involved in the production process and the conditions surrounding the industrial establishment, which are: (Callan, and Thomas, 2013: 487)

A-Reducing harmful waste at the source, including correcting the manufacturing process, modifying products, substituting appropriate alternative materials, and organizing and arranging.

B-Recycling the waste and waste generated from the manufacturing process, internally or externally, after the production process. 
C-Use of energies that are not harmful to the environment from renewable energy resources, as their impact on the environment is less harmful.

Investment models have emerged to use methods that address technical and environmental problems that accompany investments. These models include: First model: Conventional Linear or Open Material Flow Model (Cradle-toGrave Model on use): Figure (1) shows this model for balancing materials that work in one direction and enter into a production system as inputs and exit waste or waste, confirming this flow called " From cradle to grave on use" also waste generation and disposal, this model is associated with policies that aim to reduce polluted waste only at the end of the flow, for example efforts focus on the traditional clean air policy harmful from the residues emitted into the atmosphere, such as $\mathrm{CO} 2$ Sulfur oxide and particulate matter. These efforts can improve environmental quality in the short term.

Figure (1) Conventional Linear Material Flow

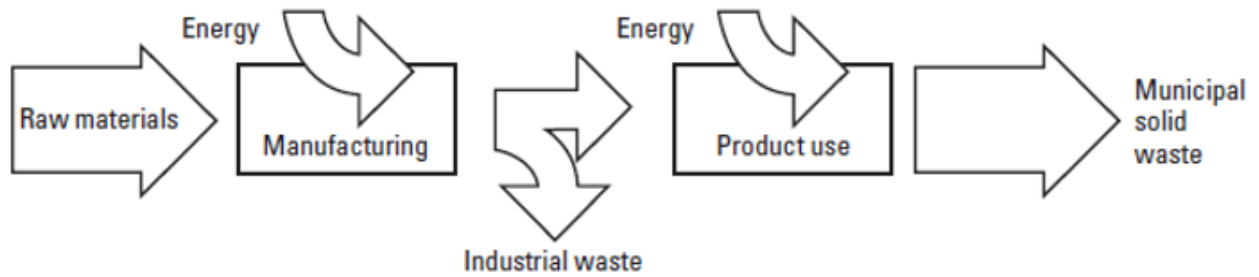

Source: Congress, OTA 1992, as cited in Gibbons, USA, 1992, P 31.

This approach has not been effective in addressing environmental damage appropriately, especially for the long-term consequences, that the realization of the causes through a review of the dynamics of the materials budget model in the context of policy initiatives, as follows: (Congress, 1992: 31)

A-Nature's ability to convert matter and energy is limited, although waste can be converted into other forms that can return to productive use; this process is not without restrictions; and policy decisions affect the use of resources and the environment. The damage has implications for future generations.

B-End-of-pipe policy controls take the form of mitigation or post-damage treatment. These techniques pull resources away from other productive activities - resources that are eventually added to the residual flow, such as working to use raw materials and energy to clean up a hazardous waste site or clean a stream contaminated water of these resources, once spent, return to the remaining flow. C-Command-and-control initiatives generally operate in conflict with private market incentives and the broader societal objective of economic growth. With this observation, he points to the potential for time trade-offs between the present and the next. The pursuit of economic development today can harm the natural environment in order to leave future generations powerless Continue this progress.

The second model: the Closed Periodic flow of Materials according to the Clean Production Approach (Cradle-to-Cradle model): that the flow of materials is not in the form of a linear picture of linear inputs through and according to production needs instead of a linear flow in the prevailing concept of treatment at the end of the pipe; it can be a design product and manufacturing processes and energy use modified to achieve a cyclical or closed flow of materials. This refers 
to a much broader scope in environmental protection approaches from the control of waste after it is generated as a result of the production process and waste prevention, energy and resource efficiency, and this design in investment for reuse or recycling are among the options proposed by the investment approach in Clean Production. In short, the main implication of the cyclical system is that the production activity can change throughout the production and consumption cycle to achieve a reduction in the negative impacts associated with the environment as well as achieving economic abundance by converting waste into new productive inputs. Life Cycle Assessment (LCA) (Cyclical or Closed Flow of Materials assumes that materials operate in a circular pattern as a closed system, to allowing waste to be returned to the production process again).

To put the concept of the periodic flow of materials into practice, it is necessary to assess the life cycle (LCA) and the possibility of implementing this tool, analytical and examine the environment and the impact of the product by re-evaluating all stages of production or extractive process of raw materials to get rid of the environmental damage caused, and additional improvements can be made to reduce the risk to the environment. In general, closed life cycle assessment consists of four main components: (EPA, 2006, 44)

A-Defining the objective and determining the scope: Describes the product or process to be evaluated, the context of the evaluation and the environmental impacts to be reviewed.

B-Stock analysis: It determines the use of natural resources and waste released into the environment.

C-Impact analysis: assesses the human and environmental impacts on the basis of actual inventory and scientific analysis.

D-Interpretation: evaluates the results of inventory and impact analysis and selects the preferred product or process. More information is available at the National Risk Management Research Laboratory.

Allowing waste to be returned to the production process as a closed system for the flow of materials as shown in Figure (2), we note that this model is an alternative to the previous model of waste control after its creation. This model shows how economic activity can be changed throughout the production and consumption cycle to reduce environmental impact associated with the production process starting with design and throughout the life cycle of the product; manufacturing processes and energy use can be modified to achieve a cyclic or closed flow of materials (Congress, 1992: 31).

Figure (2) A Closed System of Material Flow

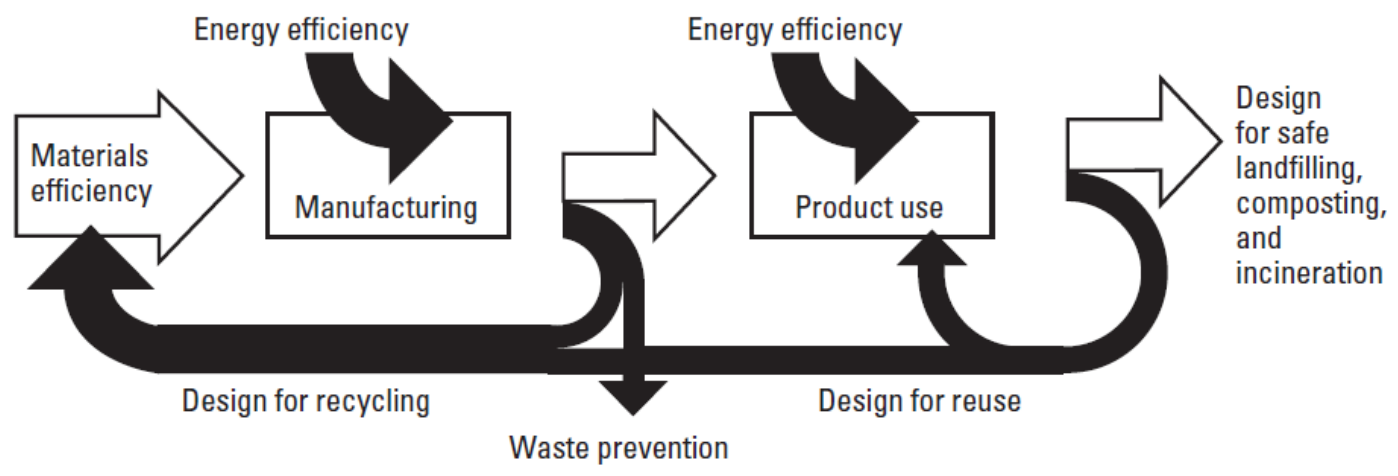


Source: Congress, OTA 1992, as cited in Gibbons, USA, 1992, P 31.

\section{4- Ur State Company trends towards the Circular Model of Clean Production:}

This company is located in Dhi Qar Province, and this company was established in 1988 after the merger of two companies, the State Company for the Aluminum Industry and the Manufacturing Company for Electrical Cables and Wires, and electrical construction establishments, and also produces aluminum products from aluminum profiles, sheets and discs, and home and office furniture industries from the primary aluminum material. The company is looking forward to meeting $(45 \%-50 \%)$ of the local demand of the private and public sector (Iraqi Ur State Company, Planning and Follow-up Department).

This company has been established since its establishment on the principle of recycling aluminum metal from local scrap waste after repurification and improvement of the metal according to the approved quality control specifications.

The company consists of two main production axes, which include production axes that contain the following production lines: (Iraqi Ministry of Justice, the legislation establishing Ur State Company 6 in 1998).

1- Group of aluminum industries factories: The production lines include: foundry factories, rolling mills, foil factories, extrusion factories 1 and 2 , and oxidation factories 1 and 2.

2- Group of factories for wires and electrical cables, and it consists of: the electrical cable factory, the telephone cable factory, the field wire factory, the control cable factory, the household wires and the wooden reel factory, and some of these factories are suspended from work in the current period of product obsolescence and the entry of modernity in technology and they are suspended in current time like telephone and control midwives.

Ur State Company of Iraq is designed to produce an amount of 7000 tons annually, because of the partial cessation and the failure to deliver aluminum waste to the official authorities led to a decline in production to 5000 tons annually, and it is one of the companies that operate according to international and Iraqi standards. For the year 2015, and in this regard, the company announces the need for $\mathbf{4 2 1 3}$ tons annually of aluminum scrap and copper scrap with an amount of 1035 tons annually. Waste within the production process in the company's factories of aluminum and copper, and the production departments re-enter them into the production process by recycling them again, and it is part of the production work since the establishment of the company as shown in the following Table (1): 
Table (1) Recyclable Waste within the Production Process of the factories of Ur Aluminum Industry in Iraq for the period (2017 - 2020)

\begin{tabular}{|c|c|c|c|c|}
\hline Years & Factory & Product Type & Waste Type & $\begin{array}{c}\text { Quantity } \\
\text { (tons/year) }\end{array}$ \\
\hline 2017 & $\begin{array}{l}\text { The Rolling Mill } \\
\text { Extrusion } \\
\text { Electrical Cable }\end{array}$ & $\begin{array}{l}\text { Sheets and Strips } \\
\text { Non-Oxidized } \\
\text { sections } \\
\text { Aluminum Wire }\end{array}$ & $\begin{array}{l}\text { Scrap }(\mathbf{A 4 , 3 0 0 3 )} \\
\text { Scrap (3063) } \\
\text { Scrap (A5L) }\end{array}$ & 81.230 \\
\hline 2018 & $\begin{array}{c}\text { The Rolling Mill } \\
\text { Extrusion } \\
\text { Electrical Cable }\end{array}$ & $\begin{array}{l}\text { Sheets and Strips } \\
\text { Non-Oxidized } \\
\text { sections } \\
\text { Aluminum Wire }\end{array}$ & $\begin{array}{l}\text { Scrap }(A 4,3003) \\
\text { Scrap (3063) } \\
\text { Scrap (A5L) }\end{array}$ & 155.658 \\
\hline 2019 & $\begin{array}{c}\text { The Rolling Mill } \\
\text { Extrusion } \\
\text { Electrical Cable }\end{array}$ & $\begin{array}{l}\text { Sheets and Strips } \\
\text { Non-Oxidized } \\
\text { sections } \\
\text { Aluminum Wire } \\
\end{array}$ & $\begin{array}{l}\text { Scrap (A4,3003) } \\
\text { Scrap (3063) } \\
\text { Scrap (A5L) }\end{array}$ & 114.353 \\
\hline 2020 & $\begin{array}{c}\text { The Rolling Mill } \\
\text { Extrusion } \\
\text { Electrical Cable }\end{array}$ & $\begin{array}{l}\text { Sheets and Strips } \\
\text { Non-Oxidized } \\
\text { sections } \\
\text { Aluminum Wire } \\
\end{array}$ & $\begin{array}{l}\text { Scrap }(A 4,3003) \\
\text { Scrap }(3063) \\
\text { Scrap (A5L) }\end{array}$ & 60.085 \\
\hline Total & - & - & - & 411.326 \\
\hline
\end{tabular}

Source: Prepared by the researchers based on: the Iraqi Ministry of Industry and Minerals, Ur State Company, Technical Department.

The table shows that the wastes of the production process are not fixed, but rather fluctuate from year to year during the comparison for the last four years, as shown in the fifth column, where the lowest amount of waste is $\mathbf{6 0 . 0 8 5}$ tons for the year 2020, and the highest amount of waste during the production process is 155.658 tons for the year 2018. This production model is one of the clean production models that adopt the modern circular production method in terms of using the term, but it is old from the practical side in Iraq, as this production pattern how can economic activity be changed throughout the production and consumption cycle to reduce the environmental impact associated with the production process began with design and throughout the cycle product life, manufacturing processes and energy use can be modified to achieve a cyclical or closed flow of materials (Congress, 1992: 31), because these materials are from production wastes that are recycled and entered into production lines again as a raw material for industry again; this method prevents the accumulation of production waste as part of the cleanliness of the industrial environment and the surrounding environment by collecting the consumer as a result of use and returning it to the industrial incubator to achieve the added value again. Table (2) shows the added value of the plumbing factory's products from the raw materials recycled aluminum metal during the four years according to the capacities and as follows: 
Table (2) The Production Capacities of the Iraqi Plumbing and Recycling Factory, the Quantity of Production and the Added Value achieved for the period

(2017 - 2020) (ton / year)

\begin{tabular}{|c|c|c|c|c|c|}
\hline Years & $\begin{array}{c}\text { Design } \\
\text { Capacity }\end{array}$ & $\begin{array}{c}\text { Available } \\
\text { Capacity }\end{array}$ & $\begin{array}{c}\text { Planned } \\
\text { Capacity }\end{array}$ & $\begin{array}{c}\text { Recycled } \\
\text { Production } \\
\text { Quantity }\end{array}$ & $\begin{array}{c}\text { Value } \\
\text { Added } \\
(\%)\end{array}$ \\
\hline 2017 & 10000 & 4000 & 600 & $\mathbf{8 9 . 6 8 0}$ & 92 \\
\hline 2018 & 10000 & 4000 & 600 & 176.868 & 92 \\
\hline 2019 & 10000 & 4000 & 600 & 122.126 & 92 \\
\hline 2020 & 10000 & 4000 & 600 & 45.320 & 92 \\
\hline Total & - & - & - & 433.994 & - \\
\hline
\end{tabular}

Source: Prepared by the researchers based on: the Iraqi Ministry of Industry and Minerals, Ur State Company, Technical Department.

The table shows the production capacities of the plumbers recycling factory, as it becomes clear that the company operates only with a production capacity to the design capacity of $6 \%$, and it works with only $15 \%$ of the available energy, and this shows the slowdown in the work of the company and this is caused by the presence of competitors for the raw materials that enter the industry, because the main material is the recycling of the metal, which the private sector establishes competition for the ores of this metal, and the verified amounts of recycled quantities represented in the best four years up to $4.4 \%$ of the available energy for the year 2018, and $3 \%$ of the available energy for the year 2019 and this explains that the company is more like a discontinued as it operates at a very low production capacity; the added value achieved is $92 \%$ of production, because the raw material and the rest of the production requirements represent only $8 \%$ of the value of the product, as it deals with aluminum waste to be returned to production, cleanliness of the environment through a clean production environment. (Iraqi Ministry of Industry and Minerals, Department of Industrial Development and Guidance, Department of Environment, 2019) and (Ministry of Industry and Minerals, Department of Planning, Department of Planning and Follow-up, 2016).

5- The Transfer to Clean Production in the State Company for Automotive and Equipment / Battery Factories:

5-1 Factories with Regular Production: These factories are located in Baghdad, Al-Waziriyah Industrial District. They are state-owned companies and are active in the manufacture of liquid and dry batteries of various sizes and measurements, and special ones according to demand. These production factories contribute to the re-use of lead, which is characterized by its environmental danger in recycling from spent batteries collected through its various outlets after crushing, sorting and extracting lead from it, to be entered as a raw material in the production of 20,000 tons of batteries annually (Iraqi Ministry of Industry and Minerals, Department of Industrial Development and Guidance, Department of Environment, 2019). 
In 2016, the battery factories estimated their annual need for recycled polypropylene plastics in production as a raw material of 500 tons annually, and in any condition and not mined, economic as well as environmental protection and cleanliness. (Iraqi Ministry of Industry and Minerals, Planning Department, Planning and Follow-up Department, 2016).

Since its inception in 1975, the factory's management has been trying to present its products in a good manner and appropriate to the ambition of the local consumer until it was merged with the State Company for the Automotive and Equipment Industry in 2016. The factory consists of a group of production lines in the form of successive production units, which are:

A-Clamps Production Unit: These are lead clamps, which are the basis for the formation of the battery cell, and their size varies according to the power of the prince to be manufactured.

B-The Ficus Unit: It is the stage in which the clamp chips manufactured in the first unit are mixed with the dough. This dough is often imported, and from it, the negative and positive electrode of the battery is determined.

C-Slide assembly unit: that works to form the cell for the battery, and at this stage the positive and negative slides overlap and an insulator separates them.

D-Welding Unit: in which the electrodes of the cells are soldered and assembled into positive and negative electrodes, and the battery is subject to a quality control system to ensure the safety of product performance.

E-Shipping Unit: In this unit, sulfuric acid, electric Shipping, and plastic cover are added. This unit takes 48 hours, 24 hours after placing the acid, and the same for the purpose of cutting and welding.

F- Packaging, Labeling and Warranty Unit: because the product becomes ready at this stage.

The old line battery factory is currently operating with a production capacity of 80-100 batteries per working day, depending on the nature and size of the battery. The daily maintenance and follow-up of acidic liquids, ionic water, poor quality and the inability of the product to compete with the same imported product, so it has become meeting the needs of the local market, which the Ministry of Planning estimates in its data at a quantity of 6 million batteries / year, and to clarify the amount of production of batteries during the past nine years in Table (3):

Table (3) The Quantity of Production of Standard Batteries for Babylon Factories for the period $(2012-2020)$

\begin{tabular}{|c|c|c|c|c|c|c|c|c|c|}
\hline Years & 2012 & $\mathbf{2 0 1 3}$ & $\mathbf{2 0 1 4}$ & $\mathbf{2 0 1 5}$ & $\mathbf{2 0 1 6}$ & $\mathbf{2 0 1 7}$ & $\mathbf{2 0 1 8}$ & $\mathbf{2 0 1 9}$ & $\mathbf{2 0 2 0}$ \\
\hline Quantities & $\mathbf{3 4 9 9 4}$ & $\mathbf{1 8 3 3 0}$ & $\mathbf{1 0 3 5}$ & $\mathbf{2 2 6 8}$ & $\mathbf{2 4 4 2}$ & $\mathbf{7 7 6 5}$ & $\mathbf{6 6 8 6}$ & $\mathbf{5 1 2 7}$ & $\mathbf{1 3 3 2}$ \\
\hline
\end{tabular}

Source: Prepared by the researchers based on: Babel Battery Factory, Statistics Department of Planning.

The decline in the quantity of production due to technical and marketing problems, as the quantity of production amounted to 1.332 standard batteries, and the quantity of production decreased to more than 27 times, and this is a dangerous indication of the efficiency of these factories from the production and environmental aspect. 
All of these stages expose workers to industrial risks because they are the closest to the production lines, which are naturally polluting to the environment as a result of the spread of solid lead, which is the primary element in this industry as it spreads in the air in the form of dusty particles that spread in the outer perimeter of the factory and pollute the air, despite the presence of air intakes and filters in the factory, which basically do not suffice for the purpose of filtering the air. The factory air filtration system suffers from obsolescence and poor performance because the air space of the factory is not tightly controlled by the filtration process, and lead particles spread with industrial water, especially those that enter production and transfer in a primitive way, where industrial water is filtered by filtration with layers of gravel and fine sand and acidic materials are treated by adding a base material to industrial water to return to the sewage networks. This process is incorrect and accurate as water sources are exposed to pollution because industrial pollutants can easily penetrate through them, as well as a percentage of damaged materials, which are assembled between production units and all of what we mentioned represents an environmental risk that transfers its role outside the factory, which reduces The environmental danger through the production process is the lack of operation and poor production, and thus the lack of industrial waste (Battery Factory, Technical Department).

The availability of the basic raw material, which is lead metal, which constitutes more than $75 \%$ of the production inputs, and it is available from the industrial policy of the state, which has been followed and still, but with less seriousness in assembling the raw material from the spent batteries and preventing its export as a raw material, as the goal of the local industry was to meet the market need in conditions of an economic siege, where the environment and the safety of workers were a secondary goal, and the main raw material is provided through directives to all state departments, including the Ministry of Defense, the Interior and all other facilities, and the private sector to re-delivery the damaged batteries to the battery factory, where it owns a factory in Abu Ghraib area (Khan Dari) for the recycling and purification of lead and the sorting of plastic battery hulls and this factory is still operating, but with decreasing efficiency, and the trend in this industry can be clarified from its production of the raw material as in the following Table (4):

Table (4) Quantities of Consumed Batteries, Waste, and Recycled in the Lead Reproduction Factory (Khan Dhari) for the period (2012-2020)

\begin{tabular}{|c|c|c|c|c|c|c|c|c|c|}
\hline $\begin{array}{c}\text { Quantities } \\
\text { (ton/year) }\end{array}$ & 2012 & 2013 & 2014 & 2015 & 2016 & 2017 & 2018 & 2019 & 2020 \\
\hline $\begin{array}{c}\text { Consumables } \\
\text { Received }\end{array}$ & 958 & 1283 & 1128 & 746 & 482 & 1313 & 695 & 655.8 & 236 \\
\hline Waste Sent & 0.00 & 0.00 & 0.00 & 30.00 & 18.71 & 34.92 & 115.16 & $\mathbf{0 . 0 0}$ & $\mathbf{0 . 0 0}$ \\
\hline $\begin{array}{c}\text { Purified } \\
\text { Recycled } \\
\text { Product }\end{array}$ & 386.28 & 301.56 & 113.55 & 65.03 & 28.07 & 102.70 & 161.71 & 32.28 & $\mathbf{0 . 6 3}$ \\
\hline $\begin{array}{c}\text { Alloy } \\
\text { Product }\end{array}$ & 214.16 & 256.91 & 129.98 & $\mathbf{0 . 0 0}$ & 26.19 & $\mathbf{5 3 . 8 8}$ & $\mathbf{2 2 . 5 5}$ & $\mathbf{4 5 . 0 4}$ & $\mathbf{3 9 . 0 3}$ \\
\hline
\end{tabular}

Source: Prepared by the researchers based on: Babel Battery Factory, Statistics Department of Planning. 
From the table that the receipt of the lead recycling and recycling factory has decreased from its rates of more than one thousand and two hundred tons to an average of 675 tons per year for the last three years (the year 2020 was taken out of the analysis because production stopped due to the pandemic). And it was transferred to the recycling factory, with the production of pure lead decreasing from 386.28 tons / year to 32.28 tons / for the year 2019, and despite the decrease in the amount of lead received from the recycling factory, the large stock of materials the primary (lead) exceeds the needs of the production capacity of the battery factory and the new factory that we will mention in the following paragraphs and for decades due to the industrial environmental policy in containing materials and returning them through the clean production method in order to prevent the exit of this element from the country. This industry has been working for decades according to the principle of clean production. The reuse of production waste and the use of the process of recycling and recycling in what is known as the circular economy are what modern industrial theories focus on, and this industry will move in the year 2021 to the cleaner production pattern through the update in the construction of the new Babylon 1 factory.

\section{5-2 Transformation of the Battery Production Factory to the Modern Cleaner}

Model: The company has taken a set of new measures to improve the competitive position of its product from the economic aspect and at the same time create an industry for a highly efficient, modern technology that takes into account the environmental aspect, by establishing a new factory (Babylon 1) instead of the old factory is located in the same location in Baghdad - Al-Waziriya, with the authorization of construction from the Italian company SOVEMA.

A-The Economic Side: This new factory operates with a production capacity of 500.000 annual batteries and is based on reducing production inputs through the use of more quality and less expensive complementary materials in the production process, such as using calcium alloy to maintain the grid shape of the cells. The price of a ton in world markets is about $\mathbf{\$ 1 0 , 0 0 0}$ instead of Allantoin (A Chemical Compound used in many Chemical Industries), which has a global price of $\$ \mathbf{2 2 , 0 0 0}$. In addition, incubators for insulating cells were made of PVC, polyethylene chloride, which is less expensive and more preserved than the old separators. It also introduced technology so that the battery works without maintenance throughout its working life, as is known in the market (Abu Al-Ain The magical), as the products of this factory do not suffer from marketing difficulties because its production targets the needs of the official departments and the needs of the Ministries of Interior and Defense, as it is estimated the need for 6,000,000 batteries annually, and this explains the existence of investment opportunities in this area to suffice the local demand as a minimum, and the factory works according to demand contracts mean that there is no storage period that is lost from the useful life of the battery and it is marketed within a guarantee period for validity and efficiency and conforming to international quality specifications.

B-Environmental Side: This industrial model operates according to environmental standards for Clean Production and circular economy, the $2 P$ anti-pollution model, as it does not leave any harm to the environment through its production stages, as it uses lead returned from the Khan Dhari factory with a purity of $\mathbf{9 9 . 9 9 \%}$, and all machines in the production lines are recycled. It is 
isolated from contact with workers, and there are air suction cups on all production machines that are tightly bound to prevent lead particles from leaking into the surrounding air. Stages and ends in obtaining pure water suitable for agriculture, and the solid materials that are generated as a result of the production process are collected to be recycled. The realization of the environmental aspect means the realization of a part of the social benefits through the absence of damage to its natural resources.

\section{6- Future Investment in the Nibras Petrochemical Industries Project:}

The Nibras project, which is expected to be implemented, is considered the third largest project in the Middle East and North Africa region. This industrial project is not new but has been since the eighties of the last century, but this project stopped working for a long time, as it was damaged, damaged and theft of its content during the wars as a result of artillery shelling for a period. The wars of the eighties and nineties and thereafter, due to the need of local industries and the desire of the state to diversify sources of income through the export of petrochemical products. The Ministry of Industry, in cooperation with the Ministry of Oil, intends to restore petrochemical plants through the Nibras project, which is located in southern Iraq in Basra Governorate, which is the best place for its proximity to the sea export outlets near the Iraqi ports. It is planned for this project to produce, in its new body, petrochemical materials, including polyethylene, which it is hoped that the produced quantity of this material will reach 1.800 million tons annually and add to the GDP approximately according to the prices of the year 2020 with an added value of 1.620 billion dollars / year at an average price $\$ 900$ per ton, and it is planned for this plant to produce three types of polyethylene: high-density, low-density, and linear-low-density polypropylene, at an average price of $\$ 900$ per ton, knowing that this price is low compared to previous periods due to the decline in global demand as a result of business scaling due to Corona pandemic, where prices before these new conditions were more than 1500 dollars per ton, and it is hoped that the demand for this material will rise in the future and prices will rise again (Iraqi Ministry of Industry and Minerals, Planning and Follow-up Department) and (Al-Jazira Capital report on petrochemical prices, monthly report on oil and petrochemical prices).

Petrochemical plants can also produce many types of different petrochemical materials with multiple uses, which are included in various industries, and for which local and global demand is expected to grow, such as naphtha, propane, butane, propylene and other industrial organic chemical petroleum derivatives. All of these types have a high market value and maximize expected revenue.

According to what is planned for this project to be in partnership with one of the international companies specialized in this type of industries at a rate of $49 \%$, and the Iraqi side of the investment by $51 \%$ of the value of the project will be divided equally between the Ministries of Industry and Minerals and the Iraqi Ministry of Oil, under the pretext of benefiting from scientific and marketing expertise. Owned by specialized international companies, it is hoped that the foundation stone for this project will be laid during the year 2021; in addition to that, the project is expected to provide 30.000 job opportunities to raise the standard of living of the residents of the region. 
This project uses the gas associated with oil extraction operations, which burns in the air as a waste and pollutes the environment in the atmosphere. It is converted as a feeder for the energy needed to operate the group of production lines for the project and for the electric power plants, which is redundant over the years of operation, and thus the environmental aspect is achieved in the use of associated gases, which is often burned to help increase the problem of global warming and depreciation of the ozone layer, where the project controls this energy through a network of pipes and tanks, and its combustion is organized and according to economic returns by using the operating energy of these factories, and these gases can be exported to maximize returns.

\section{7- Conclusions and Recommendations:}

\section{7-1 Conclusions: Through our study, we reached the following conclusions:}

A-There is a clear general trend in the transformation of most modern industries to production patterns and environmentally friendly manufacturing methods that rationalize the use of economic resources while reducing harmful environmental effects.

B-Many of the Iraqi industries were originally established on the basis of traditional production and not under the umbrella of a clean environment, and it was necessary to strengthen the role of these industries in the economic and environmental fields.

C-Despite the orientation of some industries in Iraq towards clean production, there are in fact not working on the principle of sustainability of natural resources according to the method of clean production, which leads to these industries not helping to improve the environmental reality so that this matter is a tributary of development. The Iraqi economy is supportive of it, with minimal environmental damage.

\section{7-2 Recommendations:}

A-Working seriously in harnessing technology, applied and technical sciences in directing industrial investment in Iraq towards clean products, by finding industrial alternatives that are included in cleaner production and compensating for inputs that have environmental damage.

B-Re-evaluating existing industrial projects from an environmental point of view, introducing environmental feasibility studies for modern industrial investments and obligating everyone to comply with the Iraqi environmental determinants, conditions and specifications. Environmentally friendly projects must be replaced as an alternative to polluting and harmful projects.

C-Spreading environmental awareness and culture and considering it part of the ethics of productive work, with the participation of workers, investors and all groups of Iraqi society in an ethical and environmental work that guarantees product safety, environmental safety, economic well-being and general social benefits. 


\section{References:}

1- AlJazira Capital Research and Reports Website:

https://www.aljaziracapital.com.sa/page/Research_Reports

2- Babylon battery factory, Planning Department statistics.

3- Battery Factory, Technical Department.

4- Callan, Scott J., and Thomas, Janet M., Environmental Economics \& Management: Theory, Policy, and Applications, $6^{\text {th }}$ Edition, South - Western, Cengage Learning, USA, 2013.

5- Congress, OTA 1992, as cited in Gibbons, USA, 1992.

6-El-Haggar, Salah, Sustainable Industrial Design and Waste Management, Elsevier Academic Press, Burlington, USA, 2007.

7- Environmental Protection Agency (EPA), Office of Research and Assessment, and Science Applications International Corporation, USA, 2006.

8-Iraqi Ministry of Industry and Minerals, Department of Industrial Development and Guidance, Department of Environment, 2019.

9- Iraqi Ministry of Industry and Minerals, Planning Department, Planning and Follow-up Department, 2016.

10- Iraqi Ministry of Industry and Minerals, Ur State Company, Technical Department.

11- Iraqi Ministry of Justice, Legislation to Establish Ur Public Company 6 in 1998.

12- Sabri, Muqameh, Environmental Management and Cleaner Production Technologies, Possibility of Application in the Algerian Industrial Corporation: A Case Study of Sonatrach, Journal of Research and Human Studies, 2010, Vol. 4.

13- Tahtuh, Massoud, Economic Tools in Renewable Energy, Journal of Economic Studies and Research in Renewable Energies, Faculty of Economics / Lakhdar University Batna, Algeria, 2015, Vol. 3.

14- United Nations Environment Program, Global Environment Outlook: Environment for Development, New York, United States of America, 2007.

15- Ur State Company of Iraq, Department of Planning and Follow-up. 


$$
\text { التوجهات الاستثماريت للصناعات العراقيتناحيتش الانتاج النظيف }
$$

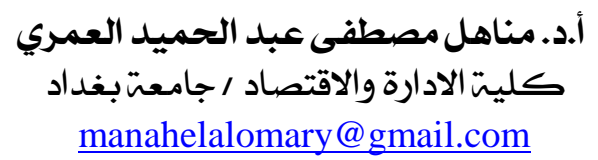

Received: 10/8/2021

Accepted: 5/9/2021

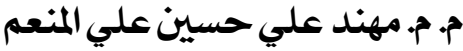 \\ كليت الادارة والاقتصاد / جامعتمبين علئداد \\ mohanadalmunim2@gmail.com
}

Published: December / 2021

هذا العمل مرخص تحت اتفاقية المشاع الابداعي نُسب المُصنَف ـ غير تجاري ـ الترخيص العمومي الدولي 4.0 Attribution-NonCommercial 4.0 International (CC BY-NC 4.0)

\section{مستخخلص البحث:}

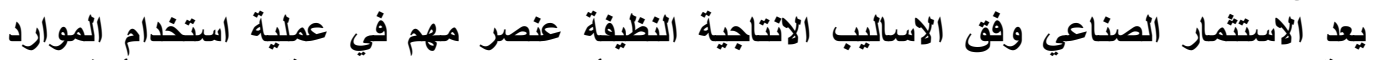

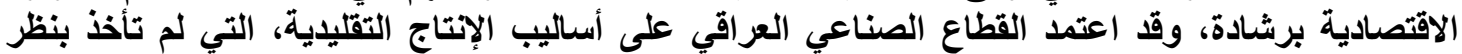

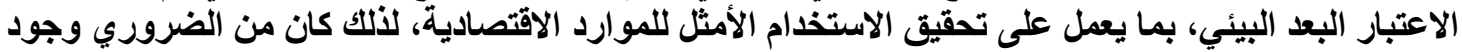

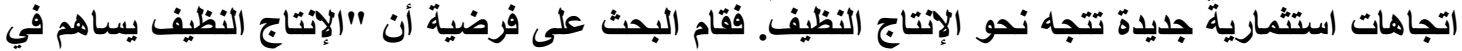

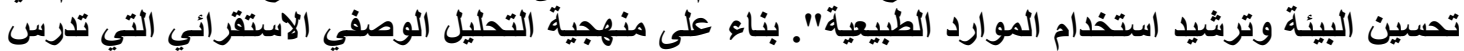

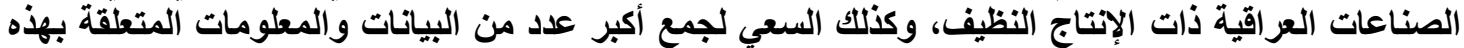

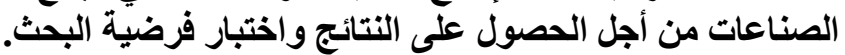

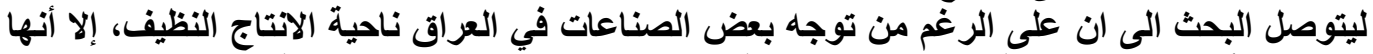

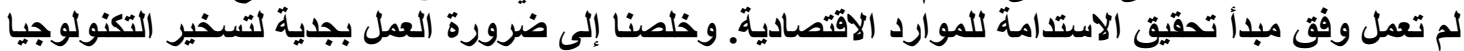

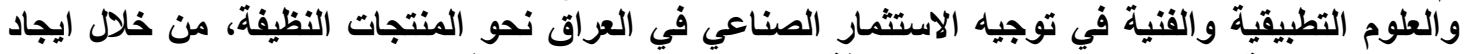

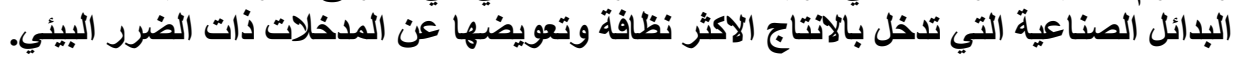

نوع البحث: تصنيف الورقة الخاصة بك تحت أحد هذه التصنيفات: ورقة بحثية تقنية ورقة مفاهيمية دراسة حالة؛ مراجعة ادبية؛ المصطلحات الرئيستّنة للبحث: الصناعات، الانتاج النظيف، الاستثمار الصناعي ، البيئة ، التدفق الخطي ، الموارد الطبيعية.

بحث مستل من اطروحة دكتوراه 